\title{
SALINE WATER AND BOVINE BIOFERTILIZER CHEMICALLY ENRICHED ON JACKFRUIT SEEDLINGS var. SOFT
}

\author{
ÁGUA SALINA E BIOFERTILIZANTE ENRIQUECIDO EM MUDAS DE JAQUEIRA \\ var. MOLE
}

\section{Francisco de Oliveira MESQUITA ${ }^{1}$; Lourival Ferreira CAVALCANTE ${ }^{\mathbf{2}}$; Jean Télvio Andrade FERREIRA ${ }^{2}$; Antônio Gustavo de Luna SOUTO ${ }^{2 *}$; Reynaldo Teodoro de FÁTIMA ${ }^{3}$; Ana Paula Pereira do NASCIMENTO ${ }^{2}$}

1. Instituto Nacional do Semiárido, Departamento de Solos, Campina Grande, PB, Brazil. 2. Programa de Pós-Graduação em Agronomia, Departamento de Fitotecnia, Campus II, Universidade Federal da Paraíba, Areia, PB, Brazil. *gusluso@hotmail.com; 3. Programa de Pós-Graduação em Engenharia Agrícola, Departamento de Engenharia Agrícola, Campus I, Universidade Federal de Campina Grande, Campina Grande, PB, Brazil.

\begin{abstract}
Water scarcity and water quality is a subject of constant debate around the world, with the accumulation of salts in water and on soils causing a negative impact on food production, man and herds, especially in the arid and semi-arid regions. The use of bovine manure biofertilizers that potentiate the use of brackish water, normally restricted in agriculture due to its salinity, has been suggested for seedling formation and crop production, including jackfruit plants. An experiment was carried out from October/2012 to February/2013, in a protected environment, at Agrarian Sciences Center, Federal University of Paraíba, Areia county, Paraíba State, Brazil, to evaluate the effects of saline water and bovine biofertilizer chemically enriched with gypsum, cow's milk and molasses. The experimental design was completely randomized, with five replications of a plant, in a factorial scheme $5 \times 2$, corresponding at values of electrical conductivity of the water of $0.5,1.0,2.0,3.0$ and $4.0 \mathrm{dS} \mathrm{m}^{-1}$ substrate with and without bovine biofertilizer. Measurements were made of substrate salinity, height of growth, stem diameter, length mean root, leaf area, leaf area ratio, and total dry mass (root, shoots and leaves). The biofertilizer enriched with cow's milk, sugar cane molasses and agricultural gypsum increased the salinity of the soil; however, it attenuated the negative effects of the salts during establishment of jackfruit seedlings, to 95 days after emergence. All the growth variables studied were higher for seedlings developed in substrate with bovine biofertilizer chemically enriched.
\end{abstract}

KEYWORDS: Artocarpus heterophyllus Lam. Attenuating. Salinity. Organic input.

\section{INTRODUCTION}

The jackfruit plant is a fruit that grows well in tropical regions, and was introduced to Brazil in the middle of the $17^{\text {th }}$ century (BERGALLO et al., 2016). The fruits of attractive shape and color, pleasant taste and aroma, are consumed directly from the plant or processed in the form of sweets, jellies and liqueur. They are rich in carbohydrates, vitamins and minerals, such as calcium and iron (MADRUGA et al., 2014). Despite these qualities and demand from consumers, production of jackfruit in Brazil is not well organized, either technically or logistically (BALIGA et al., 2011). Therefore, scientific reports on the production of seedlings, water requirements, nutritional requirements and salinity tolerance are still infrequent.

Under irrigation with salt water above 0.5 $\mathrm{dS} \mathrm{m} \mathrm{m}^{-1}$, jackfruit seedlings show a decline in growth, a reduction in dry biomass and a general loss of quality (OLIVEIRA et al., 2017; OLIVEIRA et al.,
2018). Water with salt content above the limit tolerated by the vast majority of cultivated plants is very common in arid and semi-arid regions (ALLBED; KUMAR, 2013). In these situations, salts inhibit growth, biomass production and compromise the physiological processes of plants sensitive to salt stress (SÁ et al., 2013; HUSSAIN et al., 2018).

In addition to damage to biomass, growth and formation, salinity also compromises plant physiological processes by causing stomatal closure, with decreased transpiration, influx and assimilation of $\mathrm{CO}_{2}$ (NEGRÃO; SCHMÖCKEL; TESTER, 2017). Damage also occurs by the indirect action of salts, through the loss of water extraction by plants and nutrient imbalance, in response to the low osmotic potential of the soil solution (PARIHAR et al., 2015; HUSSAIN et al., 2018). Since the twentieth century, these situations have demonstrated the need to use management and technical strategies to allow the use of water with high levels of salt in agriculture. 
One approach is the adoption of technologies to allow the use of brackish water in agriculture, without great losses in the quality of seedlings and crop yield. In this context, the bovine biofertilizer Vairo promotes greater root and aerial tissue growth, and greater formation of biomass, in comparison to plants without this organic input, during the formation of seedlings of several nonfruit and fruit species (DINIZ NETO et al., 2014; OLIVEIRA et al., 2017; LIMA NETO et al., 2018).

The promising response of plants exposed to biofertilizer under irrigation with saline water is due to humic substances that promote improvements in the structure, porosity and hydraulic conductivity of the substrate (MELLEK et al., 2010; ALENCAR et al., 2018). This advantage contributes to greater root growth and biomass allocation in comparison to plants grown on soil without biofertilizer input, as reported for noni (Morinda citrifolia; SOUTO et al., 2013), oiticica (Licania rigida; DINIZ NETO et al., 2014) and papaya (Carica Papaya; LIMA NETO et al., 2016), respectively, for seedlings grown under non-salt and salt water irrigation.

There are few reports on the use of bovine biofertilizer, chemically enriched with cow's milk, molasses and agricultural gypsum, in plants irrigated with non-saline water and water with increasing salinity. Medeiros et al. (2013) showed chemically enriched biofertilizer increased biomass in tomato-cherry (Licopersicon pimpinellifolium), under irrigation with low and high salinity water. For the growth and quality of tamarind seedlings (Tamarindus indica) irrigated with salinity water ranging from 0.5 to $6.0 \mathrm{dS} \mathrm{m}$, Lima Neto et al. (2018) concluded that enriched biofertilizer, despite not exceeding common biofertilizer, exerted a significantly higher effect on the soil without any of the inputs.

Therefore, this study evaluated the effects of irrigation with water of increasing salinity and application of biofertilizer, chemically enriched with cow's milk, molasses and agricultural gypsum, on soil salinity, and growth and quality of jackfruit seedlings var. soft.

\section{CONTENTS}

The study was conducted in a shelter at the Center of Agricultural Sciences, Federal University of Paraíba, Areia county, Paraíba State, Brazil $\left(06^{\circ}\right.$ 58' 00" S, 35 41' 00" W and $575 \mathrm{~m}$ above sea level) between October/2012 and February/2013. It was designed to evaluate the effects of irrigation with saline water and bovine biofertilizer chemically enriched use on the formation of jackfruit seedlings (Artocarpus heterophyllus Lam.) var. Soft. The climate according to the Köppen classification was As type, with dry summers and hot rains in winter (ALVARES et al., 2013). The rainy season is from March to July, with historical annual average rainfall, temperature and relative humidity of 1,400 mm, $24^{\circ} \mathrm{C}$ and $70 \%$, respectively.

The substrate, according to the criteria of the Brazilian System of Soil Classification (SiBCS; EMBRAPA, 2018), was a dystrophic Entisol. Material was collected from the $0.0-0.2 \mathrm{~m}$ layer, air dried in the shade and passed through a $2 \mathrm{~mm}$ sieve mesh. A volume of $3.5 \mathrm{dm}^{3}$ was then packed in black polyethylene bags with a capacity of $4.5 \mathrm{dm}^{3}$. Three samples of air dried earth were used for physical and chemical characterization of salinity (EMBRAPA, 2017) and saturation extract salinity (RICHARDS, 1954; Table 1).

Table 1. Physical and chemical characterization of soil fertility and salinity in the $0.0-0.2 \mathrm{~m}$ layer

\begin{tabular}{|c|c|c|c|c|c|}
\hline Physical & Value & Fertility & Value & Salinity & Value \\
\hline $\mathrm{Sd}\left(\mathrm{g} \mathrm{cm}^{-3}\right)$ & 1.51 & pH em água $(1: 2.5)$ & 6.70 & $\operatorname{ECse}\left(\mathrm{dS} \mathrm{m}^{-1}\right)$ & 0.55 \\
\hline $\mathrm{Pd}\left(\mathrm{g} \mathrm{cm}^{-3}\right)$ & 2.76 & $\mathrm{OM}\left(\mathrm{g} \mathrm{kg}^{-1}\right)$ & 13.58 & $\mathrm{pH}$ & 6.25 \\
\hline $\mathrm{Tp}\left(\mathrm{m}^{3} \mathrm{~m}^{-3}\right)$ & 0.46 & $\mathrm{P}\left(\mathrm{mg} \mathrm{dm}^{-3}\right)$ & 22.46 & $\mathrm{Ca}^{2+}\left(\mathrm{mmol}_{\mathrm{c}} \mathrm{L}^{-1}\right)$ & 1.44 \\
\hline Sand $\left(\mathrm{g} \mathrm{kg}^{-1}\right)$ & 869 & $\mathrm{~K}^{+}\left(\mathrm{cmol}_{\mathrm{c}} \mathrm{dm}^{-3}\right)$ & 0.32 & $\mathrm{Mg}^{2+}\left(\mathrm{mmol}_{\mathrm{c}} \mathrm{L}^{-1}\right)$ & 0.77 \\
\hline $\operatorname{Silt}\left(\mathrm{g} \mathrm{kg}^{-1}\right)$ & 69 & $\mathrm{Ca}^{2+}\left(\mathrm{cmol}_{\mathrm{c}} \mathrm{dm}^{-3}\right)$ & 1.50 & $\mathrm{Na}^{+}\left(\mathrm{mmol}_{\mathrm{c}} \mathrm{L}^{-1}\right)$ & 2.76 \\
\hline Clay $\left(\mathrm{g} \mathrm{kg}^{-1}\right)$ & 98 & $\mathrm{Mg}^{2+}\left(\mathrm{cmol}_{\mathrm{c}} \mathrm{dm}^{-3}\right)$ & 1.48 & $\mathrm{~K}^{+}\left(\mathrm{mmol}_{\mathrm{c}} \mathrm{L}^{-1}\right)$ & 0.53 \\
\hline $\operatorname{CDW}\left(\mathrm{g} \mathrm{kg}^{-1}\right)$ & 12 & $\mathrm{Na}^{+}\left(\mathrm{cmol}_{\mathrm{c}} \mathrm{dm}^{-3}\right)$ & 0.36 & $\mathrm{Cl}^{-}\left(\mathrm{mmol}_{\mathrm{c}} \mathrm{L}^{-1}\right)$ & 4.28 \\
\hline DF $(\%)$ & 80.45 & $\mathrm{H}^{+}+\mathrm{Al}^{3+}\left(\mathrm{cmol}_{\mathrm{c}} \mathrm{dm}^{-3}\right)$ & 2.65 & $\mathrm{CO}_{3}{ }^{2-}\left(\mathrm{mmol}_{\mathrm{c}} \mathrm{L}^{-1}\right)$ & - \\
\hline DI $(\%)$ & 19.55 & $\mathrm{Al}^{3+}\left(\mathrm{cmol}_{\mathrm{c}} \mathrm{dm}^{-3}\right)$ & 0.00 & $\mathrm{HCO}_{3}^{-}\left(\mathrm{mmol}_{\mathrm{c}} \mathrm{L}^{-1}\right)$ & 0.81 \\
\hline $\mathrm{U}_{\mathrm{fc}}\left(\mathrm{g} \mathrm{kg}^{-1}\right)$ & 12.43 & $\mathrm{SB}\left(\mathrm{cmol}_{\mathrm{c}} \mathrm{dm}^{-3}\right)$ & 4.02 & $\mathrm{SO}_{4}{ }^{2-}\left(\mathrm{mmol}_{\mathrm{c}} \mathrm{L}^{-1}\right)$ & 0.21 \\
\hline $\mathrm{U}_{\mathrm{pwp}}\left(\mathrm{g} \mathrm{kg}^{-1}\right)$ & 6.06 & $\mathrm{CEC}\left(\mathrm{cmol}_{\mathrm{c}} \mathrm{dm}^{-3}\right)$ & 6.67 & $\operatorname{SAR}\left(\mathrm{mmol} \mathrm{L}^{-1}\right)^{1 / 2}$ & 1.38 \\
\hline WA $\left(\mathrm{g} \mathrm{kg}^{-1}\right)$ & 6.37 & $\mathrm{~V}(\%)$ & 60.26 & PES $(\%)$ & 5.39 \\
\hline
\end{tabular}

$\mathrm{Sd}=$ Soil Density; $\mathrm{Pd}=$ Particle density; $\mathrm{Tp}=$ Total porosity; $\mathrm{CDW}=$ clay dispersed in water; $\mathrm{DF}=$ Degree of flocculation; DI = dispersion index; Ufc and Upwp = soil moisture at level of -0.01 and $-1.50 \mathrm{Mpa}$, respectively; $\mathrm{WA}=$ Water available; OM $=$ Organic matter; $\mathrm{SB}=$ Sum of bases $\left(\mathrm{Ca}^{2+}+\mathrm{Mg}^{2+}+\mathrm{Na}^{+}+\mathrm{K}^{+}\right) ; \mathrm{CEC}=$ Cation exchange capacity $=\mathrm{SB}+\left(\mathrm{H}^{+}+\mathrm{Al}^{3+}\right) ; \mathrm{V}=$ saturation value per base $(100 \times \mathrm{SB} / \mathrm{CEC}) ; \mathrm{ECse}=$ Electrical conductivity of the saturation extract; $\mathrm{SAR}=$ sodium adsorption ratio $=\mathrm{Na}^{+} \times\left[\left(\mathrm{Ca}^{2+}+\right.\right.$ $\left.\left.\mathrm{Mg}^{2+}\right) / 2\right]^{1 / 2} ; \mathrm{PES}=$ Percentage of exchangeable sodium $\left(100 \times \mathrm{Na}^{+} / \mathrm{CEC}\right)$. 
The design of the experiment was completely randomized, with five replications using the factorial scheme $5 \times 2$, corresponding to electrical conductivity values of the irrigation water (CEiw) of 0.5, 1.0, 2.0, 3.0 and $4.0 \mathrm{dS} \mathrm{m}^{-1}$ on a substrate with and without $350 \mathrm{~mL}$ of chemically enriched bovine biofertilizer applied only once, two days before sowing. Seeds of jackfruit var. Soft were obtained from fruits of free standing plants grown at the nursery of the Federal University of Paraíba, Areia, Paraíba, Brazil.

The values of electrical conductivity of water above $0.5 \mathrm{dS} \mathrm{m}^{-1}$ were obtained by diluting strongly saline dam water $\left(15.12 \mathrm{dS} \mathrm{m}^{-1}\right)$ in nonsaline water $\left(0.5 \mathrm{dS} \mathrm{m}^{-1}\right)$. Equation (1) and portable conductivity meter Instrutherm (CD-860) were used to determine the electrical conductivity.

$$
\mathrm{V}_{1} \mathrm{C}_{1}=\mathrm{V}_{2} \mathrm{C}_{2} \text { (Eq. 1) }
$$

where: V1 = constant volume of strongly saline water to obtain the volume of water with the pre-established electrical conductivity $\left(\mathrm{dm}^{3}\right) ; \mathrm{C}_{1}=$ electrical conductivity of strongly saline water (dS $\left.\mathrm{m}^{-1}\right) ; \mathrm{V}_{2}=$ volume of non-saline water $\left(0.5 \mathrm{dS} \mathrm{m}^{-1}\right)$ to obtain a mixture with the desired electrical conductivity $\left(\mathrm{dm}^{3}\right)$; and $\mathrm{C}_{2}=$ electrical conductivity of the desired water $\left(\mathrm{dS} \mathrm{m}^{-1}\right)$.

The bovine biofertilizer enriched was obtained by anaerobic fermentation in a biodigester containing equal parts of water and fresh bovine manure, chemically enriched with $4 \mathrm{dm}^{3}$ of molasses, $8 \mathrm{dm}^{3}$ of bovine milk and $4 \mathrm{~kg}$ of agricultural gypsum, giving a ratio of 1:2:1. To maintain the hermetically sealed system, one end of a $4 \mathrm{~mm}$ diameter plastic hose was connected to the upper base of the biodigester and its other end was immersed in a vessel with water, to allow pressure release without environmental contamination of the system. The biofertilizer was evaluated as water for irrigation (Table 2) using the methodologies recommended by Richards (1954).

Table 2. Chemical characterization of irrigation water and chemically enriched bovine biofertilizer

\begin{tabular}{lllc}
\hline Compounds & $\begin{array}{l}\text { Non - saline } \\
\text { water }\end{array}$ & Saline water & $\begin{array}{c}\text { Enriched } \\
\text { bovine biofertilizer }\end{array}$ \\
\hline $\left.\mathrm{EC}(\mathrm{dS} \mathrm{m})^{-1}\right)$ & 0.51 & 15.12 & 6.28 \\
$\mathrm{SAR}\left(\mathrm{mmol} \mathrm{L}^{-1}\right)^{1 / 2}$ & 2.44 & 20.80 & 2.29 \\
$\mathrm{Ca}^{2+}\left(\mathrm{mmol}_{\mathrm{c}} \mathrm{L}^{-1}\right)$ & 1.37 & 10.83 & 20.48 \\
$\mathrm{Mg}^{2+}\left(\mathrm{mmol}_{\mathrm{c}} \mathrm{L}^{-1}\right)$ & 0.83 & 37.53 & 13.82 \\
$\mathrm{Na}^{+}\left(\mathrm{mmol}_{\mathrm{c}} \mathrm{L}^{-1}\right)$ & 2.56 & 102.29 & 9.51 \\
$\mathrm{~K}^{+}\left(\mathrm{mmol}_{\mathrm{c}} \mathrm{L}^{-1}\right)$ & 0.19 & 2.69 & 17.42 \\
$\mathrm{Cl}^{-}\left(\mathrm{mmol}_{\mathrm{c}} \mathrm{L}^{-1}\right)$ & 3.48 & 111.60 & 27.93 \\
$\mathrm{HCO}^{-}\left(\mathrm{mmol}_{\mathrm{c}} \mathrm{L}^{-1}\right)$ & 0.45 & 40.49 & 8.98 \\
$\mathrm{CO}^{2-}{ }_{3}\left(\mathrm{mmol}_{\mathrm{c}} \mathrm{L}^{-1}\right)$ & 0.00 & 2.10 & 0.00 \\
$\mathrm{SO}^{2-}\left(\mathrm{mmol}_{\mathrm{c}} \mathrm{L}^{-1}\right)$ & 0.76 & 0.80 & 15.52 \\
\hline $\mathrm{Classification}$ & $\mathrm{C}_{1} \mathrm{~S}_{1}$ & $\mathrm{C}_{4} \mathrm{~S}_{2}$ & $\mathrm{C}_{2} \mathrm{~S}_{1}$ \\
\hline
\end{tabular}

$\mathrm{EC}=$ electrical conductivity; $\mathrm{SAR}=$ sodium adsorption ratio $\left.=\mathrm{Na}^{+} \times\left[\left(\mathrm{Ca}^{2+}+\mathrm{Mg}^{2+}\right) / 2\right)\right]^{1 / 2} ; \mathrm{C}_{1}, \mathrm{C}_{2}$ and $\mathrm{C}_{4}=$ low, medium and high risk to salinizing the soil, respectively; $\mathrm{S}_{1}$ and $\mathrm{S}_{2}=$ low and high risk of promoting soil sodicity, respectively.

Five jackfruit seeds with a viability of $92 \%$ were sown in each experimental unit. At 15 days after emergence (DAE), thinning was performed, maintaining the more vigorous seedlings. Irrigation with water of defined salinity was done by the weighing method. The evapotranspiration volume every $24 \mathrm{~h}$ was provided to maintain the soil moisture near $90 \%$ of the field capacity, to avoid leaching of the applied organic material.

At $95 \mathrm{DAE}$, at the end of the experiment, soil samples were collected for evaluation of their salinity by electrical conductivity of the saturation extract (ECse). At the same time, plant height $(\mathrm{PH})$ and root length of the plants (RL) were measured with a millimeter ruler, stem diameter was determined with a Digimess 300 digital caliper, and leaf area (LA) obtained with a LI-300C portable LA meter. Root and aerial tissue was collected separately, and dried in an oven with air circulation at a temperature of $65^{\circ} \mathrm{C}$ for a period of 72 hours, to constant mass. Dry mass of roots and aerial tissue were obtained on a semi-analytic balance, with their sum providing the total dry mass (TDM). The leaf area ratio (LAR) was determined by the ratio between LA and TDM for the seedlings (BENINCASA, 2003).

The Dickson quality index (DQI) was determined using the methodology contained in Dickson, Leaf and Hosner (1960), according to equation (2): 
$\mathrm{DQI}=\mathrm{TDM}[(\mathrm{PH} / \mathrm{SD})+(\mathrm{DMAT} / \mathrm{DMR})]($ Eq. 2)

where: DQI = Dickson quality index; TDM $=$ total dry matter $(\mathrm{g}) ; \mathrm{PH}=$ plant height $(\mathrm{cm}) ; \mathrm{SD}=$ stem diameter $(\mathrm{mm})$; DMAT $=$ dry mass of aerial tissue $(\mathrm{g})$; and $\mathrm{DMR}=$ dry mass of roots $(\mathrm{g})$.

The results were submitted to analysis of variance (ANOVA) by the F-test $(p<0.05)$. The biofertilizer averages were compared by F-test ( $p$ $<0.05$ ), which was conclusive for two values from the same source of variation. The averages for the electrical conductivity of irrigation water were
MESQUITA, F. O. et al.

analyzed by regression at 5\% of probability, using statistical software Sisvar 5.6 (FERREIRA, 2014).

The interaction between water salinity and the chemically enriched bovine biofertilizer had significant effects on soil salinity and on the growth and quality of jackfruit seedlings by the end of the experiment (Table 3). Similar soil and plant responses were recorded by Medeiros et al. (2013) and Lima Neto et al. (2018), when they concluded that the interaction of saline water and biofertilizer, enriched with cow's milk, molasses and agricultural gypsum, exerted significant effects on the growth and biomass of cherry tomato plants and the formation of tamarind seedlings.

Table 3. Summary of the analysis of variance for the electrical conductivity of soil saturation extract (ECse), plant height (PH), stem diameter (SD), root length (RL), leaf area (LA), leaf air ratio (LAR), total dry mass (TDM), and Dickson quality index (DQI) in leaves of jackfruit seedlings, as a function of water salinity and chemically enriched bovine biofertilizer

\begin{tabular}{|c|c|c|c|c|c|c|c|c|c|}
\hline \multirow{2}{*}{ SV } & \multirow{2}{*}{ DF } & \multicolumn{7}{|c|}{ Square Mean } & \multirow[b]{2}{*}{ DQI } \\
\hline & & ECse & $\mathrm{PH}$ & SD & RL & LA & LAR & TDM & \\
\hline Sal (S) & 4 & $16.68^{* *}$ & $29.33^{\mathrm{ns}}$ & $1.13^{* *}$ & $248.35^{* *}$ & $4382.15^{* *}$ & $1018.96^{* *}$ & $7.03^{* *}$ & $0.430^{* *}$ \\
\hline Bio (B) & 1 & $36.98^{* *}$ & $369.92^{* *}$ & $58.32^{* *}$ & $5.78^{\mathrm{ns}}$ & $44045.12^{* *}$ & $1478.04^{* *}$ & $2.88^{* *}$ & $0.310^{* *}$ \\
\hline $\mathrm{S} \times \mathrm{B}$ & 4 & $2.28^{* *}$ & $97.970^{*}$ & $3.37^{* *}$ & $124.13^{* *}$ & $2187.47^{* *}$ & $375.62^{* *}$ & $1.83^{* *}$ & $0.018^{*}$ \\
\hline Resíduo & 40 & 0.14 & 18.02 & 0.19 & 12.32 & 414.36 & 42.11 & 0.41 & 0.006 \\
\hline $\mathrm{CV}(\%)$ & & 10.81 & 11.16 & 8.79 & 9.72 & 10.60 & 13.49 & 15.39 & 15.79 \\
\hline
\end{tabular}

$\mathrm{SV}=$ source of variation; $\mathrm{DF}=$ degrees of freedom; $\mathrm{CV}=$ coefficient of variation; $\mathrm{ns}=$ non-significant. $*$ and $* *$, significant at $5 \%$ and $1 \%$ of probability by the F-test, respectively.

Soil salinity increased linearly to levels of 0.3310 and 0.6406 per unit increase of the electrical conductivity of the irrigation water in treatments without and with enriched biofertilizer, respectively, with soil showing superiority with the organic input (Figure 1). The values increased from 1.09 to 3.34 $\mathrm{dS} \mathrm{m}{ }^{-1}$ and from 3.28 to $4.45 \mathrm{dS} \mathrm{m}^{-1}$ for plants irrigated with water of 0.5 and $4.0 \mathrm{dS} \mathrm{m} \mathrm{m}^{-1}$, respectively, in soil without and with chemically enriched biofertilizer. The highest values for high electrical conductivity were the result of input of $6.28 \mathrm{dS} \mathrm{m}^{-1}$ water (Table 2), which contributed to the superiority of the saline character of the soil. For the waters of electrical conductivity $0.5,1.0,2.0,3.0$ and $4.0 \mathrm{dS} \mathrm{m}^{-1}$, those treated with chemically enriched biofertilizer showed 201.8, 158.2, 92.7, 59.1 and $33.5 \%$ superiority in growth over plants without the biofertilizer. Despite the high values, compared to the initial level of $0.55 \mathrm{dS} \mathrm{m}^{-1}$ (Table 1), soil salinity at the end of the experiment, of 3.34 and $4.46 \mathrm{dS} \mathrm{m}^{-1}$, did not reach the salinity reported by Richards (1954), with electrical conductivities > $8 \mathrm{dS} \mathrm{m}^{-1}$.

For Richards (1954), the salinity of the water treatments increased the condition of nonsaline soil (CEes $<2 \mathrm{dS} \mathrm{m}^{-1}$ ) to slightly saline (4> CEs $\left.>2 \mathrm{dS} \mathrm{m}^{-1}\right)$ and medium saline (4dS m $\left.\mathrm{m}^{-1}\right)$ soil, without and with bovine biofertilizer chemically enriched, respectively. However, even when not strongly saline, electrical conductivity values can inhibit the growth and quality of seedlings of susceptible and moderately salt-sensitive species (HOLANDA et al., 2016), including jackfruit (OLIVEIRA et al., 2017). 


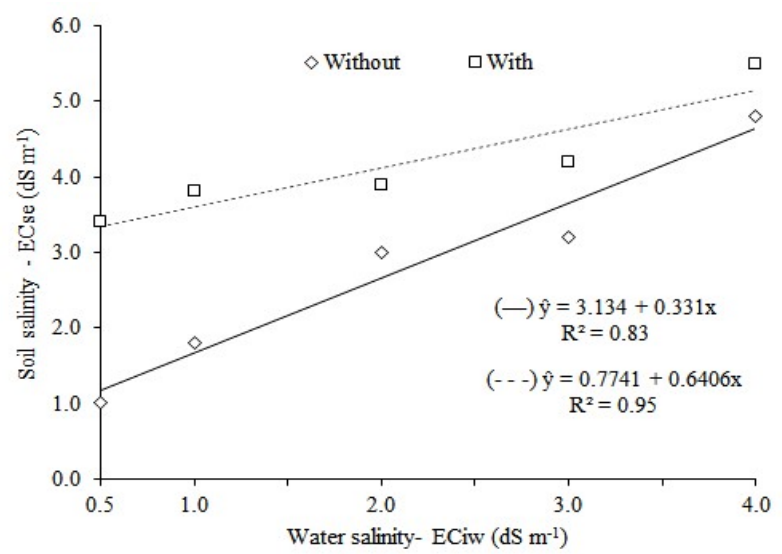

Figure 1. Electrical conductivity of soil saturation extract without $(-)$ and with (---) chemically enriched bovine biofertilizer, as a function of salinity of irrigation water.

The enriched biofertilizer, despite raising the saline level of the soil, inhibited the adverse effects of irrigation water salinity. This conclusion was based on increased height, stem diameter and main root length in jackfruit, compared to plants
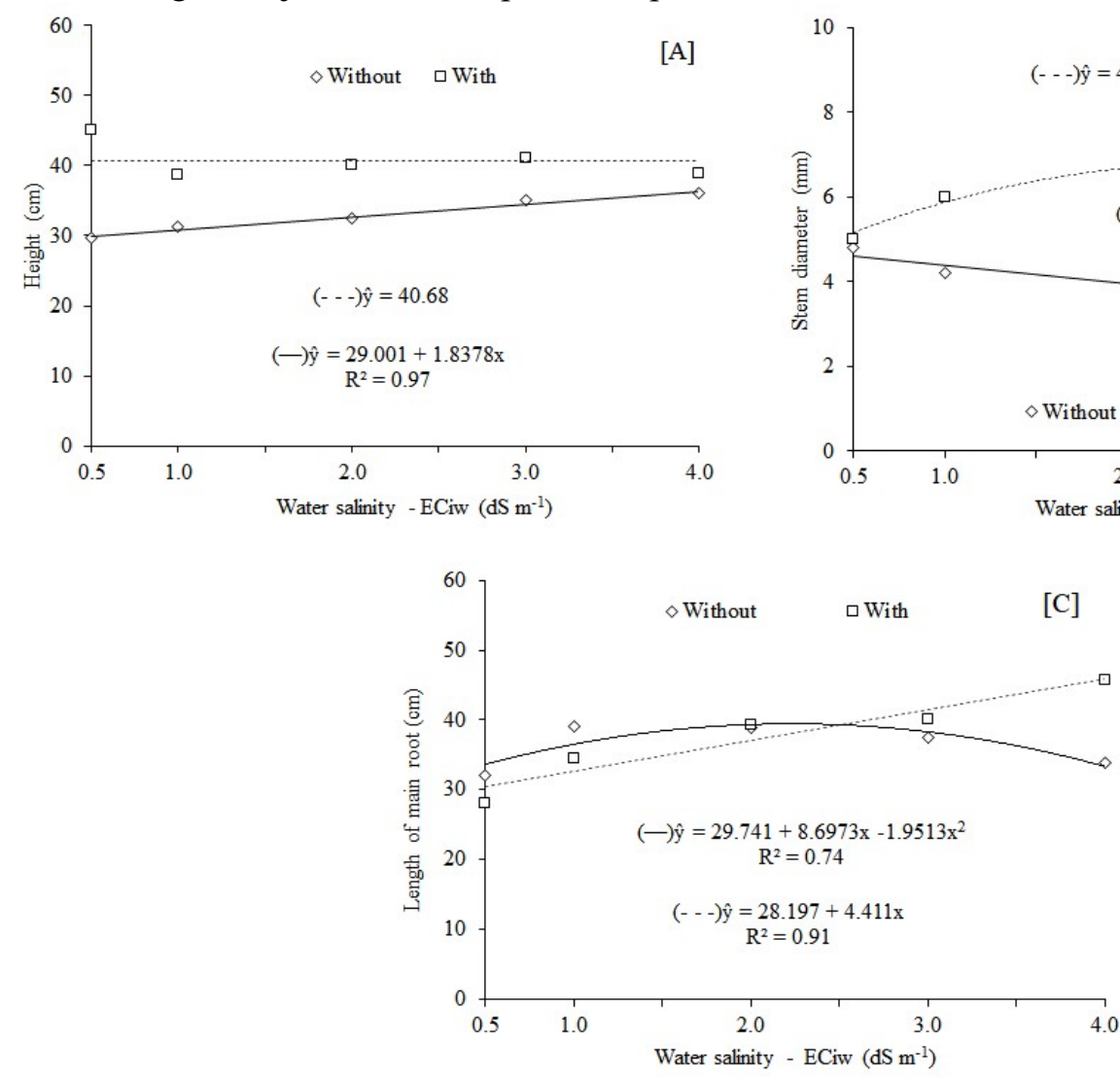

Figure 2. Growth in height (A), stem diameter (B) and length of main root (C) for seedlings of jackfruit irrigated with waters of increasing salinity, in soil without (-) and with (---) chemically enriched bovine biofertilizer.

The height of seedlings of jackfruit in soil without biofertilizer increased linearly with increasing water salinity from 29.54 to $36.35 \mathrm{~cm}$, resulting in a $23.1 \%$ increase between water treatments of 0.5 and $4.0 \mathrm{dS} \mathrm{m}^{-1}$ (Figure 2A). This grown in soil without enriched biofertilizer (Figure 2 ). These results were consistent with those obtained in noni (SOUTO et al., 2013) and papaya (LIMA NETO et al., 2016) seedlings, in soil with a similar biofertilizer.

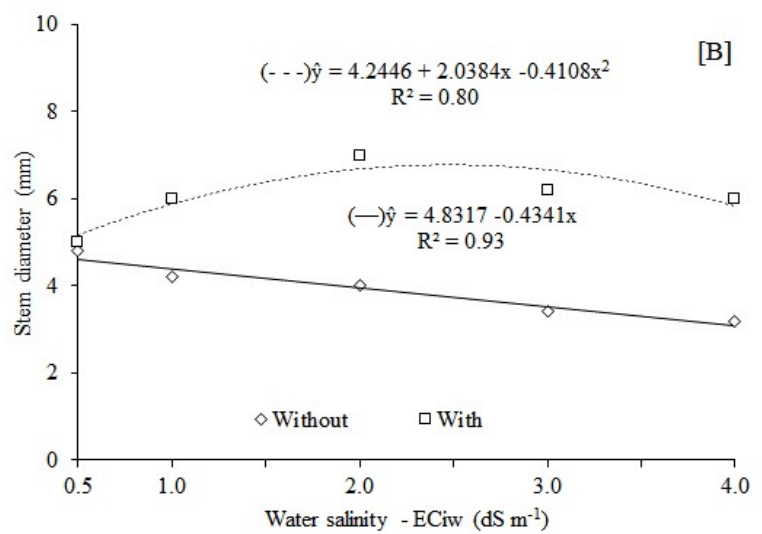

[C]

was in contrast to previous reports, where, in general, an increase in saline water concentration inhibited the growth of plants (SÁ et al., 2015), including jackfruit (OLIVEIRA et al., 2017; OLIVEIRA et al., 2018). In soil with the organic 
input, the height data of the seedlings did not fit any regression model, due to the increase in the electrical conductivity of the waters, presenting an average value of $40.68 \mathrm{~cm}$; however, they were higher than for plants in soil without biofertilizer (Figure 2A). The greater plant growth of seedlings that developed in soil with enriched biofertilizer was likely due to humic substances complexing salts (OUNI et al., 2014), improved hydraulic conductivity, structure and macro porosity of the soil (MELLEK et al. al., 2010), and increased availability of essential nutrients (ALVES et al., 2009).

Increase of salts in the irrigation water linearly inhibited stem diameter of jackfruit seedlings in soil without chemically enriched biofertilizer, in the proportion of $0.4108 \mathrm{~mm}$ per unit increase of the electrical conductivity of the water. By contrast, biofertilizer stimulated the growth of stem diameter in seedlings irrigated with water of maximum salinity estimated at $2.5 \mathrm{dS} \mathrm{m}^{-1}$ (Figure 2B). For plants in soils without and with enriched biofertilizer, stem diameter showed a loss of $18.4 \%$ and a gain of $31.2 \%$, respectively, when comparing plants that were grown at $0.5 \mathrm{dS} \mathrm{m}^{-1}$ and $2.5 \mathrm{dS} \mathrm{m}^{-1}$.

The salinity of the irrigation water reduced the ability of the roots to extract water from the substrate, which negatively interfered with photosynthetic processes and $\mathrm{CO}_{2}$ assimilation, leading to a decrease in cell division and expansion (PARIHAR et al., 2015; NEGRÃO; SCHMÖCKEL; TESTER, 2017). However, because the enriched biofertilizer contained osmoregulatory substances such as potassium, its inclusion promoted greater absorption of water and nutrients by plants (ALENCAR et al., 2018).

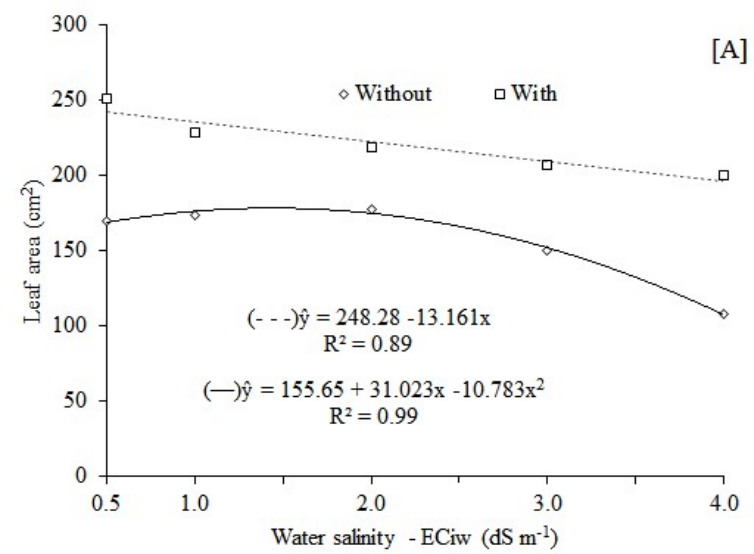

Increase of irrigation water salinity in most treatments stimulated root growth of jackfruit seedlings, with the positive influence being most evident for soils containing enriched biofertilizer and irrigated with higher levels of water salinity (Figure 2C). The length of the main root of seedlings in soil without biofertilizer grew under irrigation with water of up to $2.2 \mathrm{dS} \mathrm{m}^{-1}$, reaching the highest value of $39.43 \mathrm{~cm}$. This increase in root growth in saline conditions might be a response of the seedlings to the adverse osmotic environment actively promoting greater growth (HUSSAIN et al., 2018).

In the soil with chemically enriched bovine biofertilizer, root growth increased linearly from 30.40 to $45.84 \mathrm{~cm}$ between plants irrigated with water of 0.5 and $4.0 \mathrm{dS} \mathrm{m}^{-1}$, representing a gain of $50.8 \%$. Similar behavior was observed for root growth in oiticica (Licania rigida Benth) seedlings irrigated with saline waters (DINIZ NETO et al., 2014). The biofertilizer, through its contribution of humic substances, promoted improvements in physical attributes of the soil, mainly in structure and porosity, which resulted in higher root growth under saline conditions (ALENCAR et al., 2018).

The chemically enriched biofertilizer also inhibited the negative effects of water salinity on LA and LAR of jackfruit seedlings in comparison to plants in soil without the biofertilizer (Figure 3). The change in electrical conductivities of the irrigating waters caused a loss of $23.2 \%$ and a gain of $5.6 \%$ in LA for soil with and without the biofertilizer, respectively. However, the absolute value ranges of $254.86-195.64 \mathrm{~cm}^{2}$ and $168.47-$ $177.95 \mathrm{~cm}^{2}$, respectively, illustrated the positive effect of the chemically enriched biofertilizer in attenuating the adverse effects of all salinities (Figure 3A).

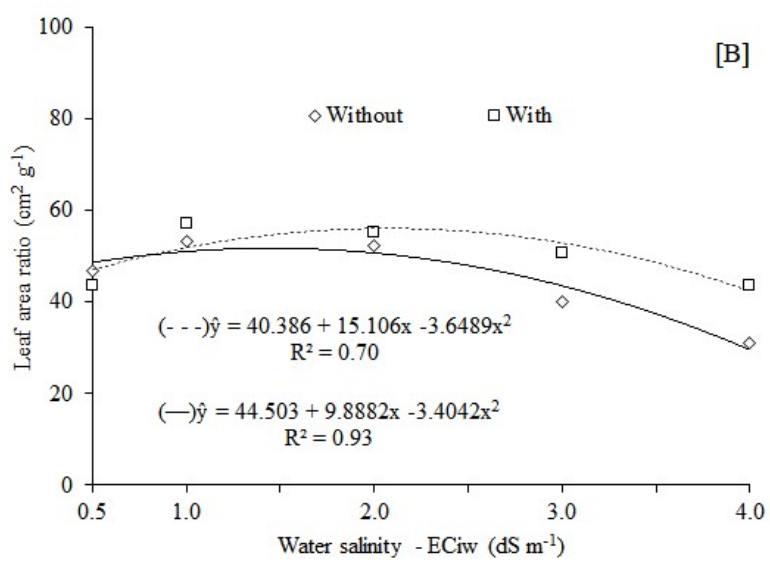

Figure 3. Leaf area (A) and leaf area ratio (B) of jackfruit seedlings irrigated with waters of increasing salinity, in soil without (-) and with (---) chemically enriched bovine biofertilizer. 
In soil with similar biofertilizer or the biofertilizer Vairo, Diniz Neto et al. (2014) showed a similar trend for oiticica seedlings irrigated with saline water, with loss of LA on increasing electrical conductivity of water from 0.5 to $6.0 \mathrm{dS} \mathrm{m}^{-1}$. It was also consistent with Souto et al. (2013), who observed a reduction of $35 \%$ in LA for noni plants irrigated with waters of the same electrical conductivity levels as the current study, but always with higher leaf areas in the seedlings treated with the organic input. The higher data values of plants in soil with enriched biofertilizer compared to those in soil without this input were consistent with findings for tamarind seedlings irrigated with water of increasing salinity (LIMA NETO et al., 2018).

For soil without and with chemically enriched biofertilizer, with increased water salinity irrigation from 0.5 to $1.5 \mathrm{dS} \mathrm{m}^{-1}$ and from 0.5 to 2.1 $\mathrm{dS} \mathrm{m}^{-1}$, an increased LAR was observed from 48.59 to $51.64 \mathrm{~cm}^{2} \mathrm{~g}^{-1}$ and from 47.03 to $56.02 \mathrm{~cm}^{2} \mathrm{~g}^{-1}$, an increase of 6.3 and $19.1 \%$, respectively (Figure 3B). When comparing the LAR of irrigated seedlings irrigated with water of 1.5 and $2.1 \mathrm{dS} \mathrm{m}^{-1}$, in the absence and presence of enriched biofertilizer, there was a 6.2 and $11.5 \%$ increase, respectively.

This situation indicated a greater efficiency of leaves in transforming absorbed light per unit of biomass produced (DUNEA; NEAGU FRĂSIN; DINCĂ, 2015), and as for growth in height, stem diameter and main root length, indicated the effect of the biofertilizer in mitigating the adverse effects of increased salt concentrations for jackfruit with regard to their leaves. The biofertilizer, because it contains all the essential macronutrients, even if at low levels (ALVES et al., 2009), and provides organic solutes that regulate the osmotic environment (SOUSA et al., 2014), should contribute to a greater absorption of water and nutrients by plants under adverse conditions of salinity (SÁ et al., 2013).

Increases in saline water concentration linearly inhibited the formation of dry biomass for seedlings in the soil with biofertilizer. However, the inhibition was greater for plants grown without biofertilizer and irrigated with water of estimated maximum electrical conductivity of $2.0 \mathrm{dS} \mathrm{m}^{-1}$ (Figure 4). With the exceptions of water of 2.0 and $3.0 \mathrm{dS} \mathrm{m}^{-1}$, seedlings in enriched biofertilizer had higher total dry biomasses than those grown without biofertilizer.

The increase in total dry biomass of seedlings in soil without organic input and irrigated with water of up to $2.0 \mathrm{dS} \mathrm{m}^{-1}$ indicated jackfruit, during this phase of development, were only moderately sensitive to water salinity, compared to other crops (DIAS et al., 2016). However, these results were in contrast to Oliveira et al. (2018) who found that total dry mass of jackfruit seedlings was linearly inhibited with increase in water salinity from 0.3 to $4.0 \mathrm{dS} \mathrm{m}^{-1}$.

For plants in soil with enriched biofertilizer, total dry mass of plants decreased linearly from 5.30 to $3.53 \mathrm{~g}$, a loss of $33.4 \%$, for seedlings irrigated with water of 0.5 and $4.0 \mathrm{dS} \mathrm{m}^{-1}$, respectively. This reduction, also observed in other variables, could be caused by a decrease in water absorption in response to the saline complex of osmotic effect and excess of specific ions. The toxic and nutritional imbalance might simultaneously affect photosynthetic processes, carbon assimilation, chlorophyll degradation and photo-assimilation, with resulting negative effects on plants (SHELDON et al., 2017). Similar behavior was observed by Sá et al. (2015), who found a decline in total dry mass for sugarapples (Annona squamosa) of $0.0923 \mathrm{~g}$ per unit increase in the electrical conductivity of irrigation water.

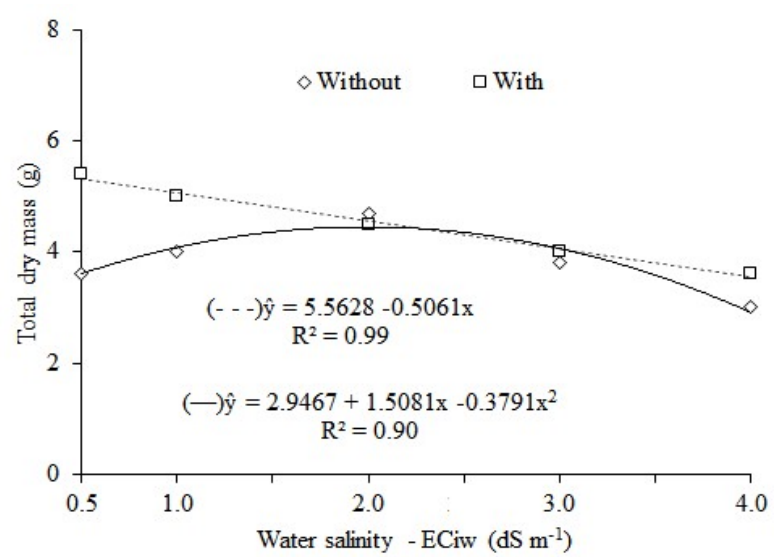

Figure 4. Total dry mass of jackfruit seedlings irrigated with water of increasing salinity, in soil (-) without and with (---) chemically enriched bovine biofertilizer. 
An increase in salt content of water from 0.5 to 2.1 and 0.5 to $1.8 \mathrm{dS} \mathrm{m}^{-1}$ resulted in improved quality of jackfruit seedlings, in soil without and with chemically enriched biofertilizer, with the highest values of 0.50 and 0.63 in the DQI, respectively (Figure 5). These results were consistent with 0.65 and $>0.50$, respectively, obtained by Oliveira et al. (2017) for jackfruit seedlings under irrigation with saline water in
MESQUITA, F. O. et al.

substrate without and with added nitrogen. When comparing the results at values of maximum salinity estimated at 1.8 and $2.1 \mathrm{dS} \mathrm{m}^{-1}$, there was a 26.0 and $23.5 \%$ increase in DQI for jackfruit seedlings in soil with bovine biofertilizer, compared to those in soil without biofertilizer, once again indicating the positive effect of the chemically enriched biofertilizer in attenuating the harmful effects of salinity on the formation of jackfruit seedlings.

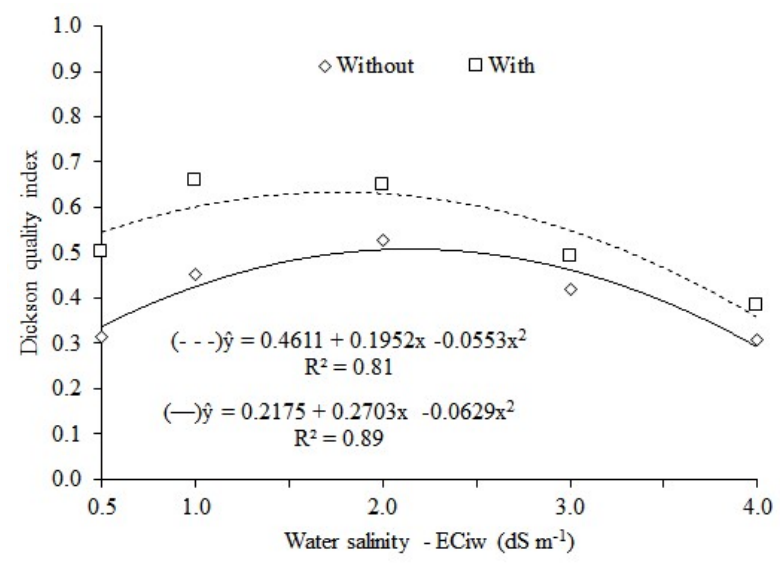

Figure 5. Dickson Quality Index in jackfruit seedlings irrigated with water of increasing salinity, in soil without (-) and with (---) chemically enriched bovine biofertilizer.

The bovine biofertilizer chemically enriched, in spite of increasing soil salinity, exerts an attenuating action on the salts, as observed during the formation of jackfruit seedlings irrigated with waters of increasing salinity. All growth variables were higher in soil with bovine biofertilizer enriched with milk, sugar cane molasses and agricultural gypsum. The best quality jackfruit seedlings were obtained in soil with enriched bovine biofertilizer, irrigated with water of up to $2.1 \mathrm{dS} \mathrm{m}^{-1}$.

RESUMO: A escassez e a qualidade da água são assuntos de constante debate em todo o mundo, com o acúmulo de sais na água e nos solos, causando um impacto negativo na produção de alimentos, homem e rebanhos, especialmente nas regiões áridas e semiáridas. O uso de biofertilizante de esterco bovino que possibilita o uso de água salobra, normalmente restrita à agricultura devido à salinidade, tem sido sugerido para formação demudas e produção agrícola, inclusive de jaqueira. Um experimento foi desenvolvido entre outubro de 2012 e fevereiro de 2013, em ambiente protegido, no Centro de Ciências Agrárias, da Universidade Federal da Paraíba, Areia, Paraíba, Brasil, para avaliar os efeitos da água salina e biofertilizante bovino enriquecido quimicamente com calcário, leite de vaca e melaço. O delineamento experimental foi inteiramente casualizado, com cinco repetições e uma planta, em esquema fatorial $5 \times 2$. Água com condutividade elétrica de $0,5,1,0$, 2,0, 3,0 e 4,0 foram aplicadas no substrato com e sem biofertilizante bovino. Foi avaliada a salinidade do substrato, crescimento em altura, diâmetro caulinar, crescimento da raiz principal, área foliar, razão de área foliar e massa seca total (raiz, parte aérea e folhas). O biofertilizante enriquecido com leite de vaca, melaço de cana-de-açúcar e gesso agrícola aumentou a salinidade do solo, no entanto, atenuou os efeitos negativos da salinidade durante o estabelecimento das mudas de jaqueira, aos 95 dias após a emergência. Todas as variáveis estudadas foram maiores nas mudas que cresceram no substrato com biofertilizante enriquecido quimicamente.

PALAVRAS-CHAVE: Artocarpus heterophyllus Lam. Atenuante. Insumo orgânico. Salinidade 


\section{REFERENCES}

ALENCAR, T. L.; AQUINO SOUSA, L. F. R.; CHAVES, A. F.; MOTA, J. C. A. Response function for the Srelative index in Cambisol treated with and without bovine liquid biofertilizer. Revista Caatinga, Mossoró, v.31, n.2, p. 466-475, 2018. https://doi.org/10.1590/1983-21252018v31n223rc

ALLBED, A.; KUMAR, L. Mapeamento e monitoramento da salinidade do solo em regiões áridas e semiáridas utilizando tecnologia de sensoriamento remoto: uma revisão. Revista de Geografia, Recife, v. 2, n. 4 , p.373-385, 2013.

ALVARES, C. A.; STAPE, J. L.; SENTELHAS, P. C.; GONÇALVES, J. L. M.; SPAROVEK, G. Köppen's climate classification map for Brazil. Meteorologische Zeitschrift, Berlin, v. 22, n. 6, p. 711-728, 2013. https://doi.org/10.1127/0941-2948/2013/0507

ALVES, G. S.; NASCIMENTO, J. A. M.; SANTOS, D.; ALVES, S. S. V.; SILVA, J. A. Fertilidade do solo cultivado com pimentão sob aplicação de diferentes tipos biofertilizantes. Revista Verde de Agroecologia e Desenvolvimento Sustentável, Mossoró, v. 4, n. 4, p. 33-41, 2009.

BALIGA, M. S.; SHIVASHANKARA, A. R.; HANIADKA, R.; DSOUZA, J.; BHAT, H.P. Phytochemistry, nutritional and pharmacological properties of Artocarpus heterophyllus Lam (jackfruit): A review. Food Research International, Barking, v.44, n.8, p.1800-1811, 2011. https://doi.org/10.1016/j.foodres.2011.02.035

BENINCASA, M. M. P. Análise de crescimento de plantas: noções básicas. Jaboticabal: FUNEP, 2003. 42 p.

BERGALlO, H. G.; BERGALLO, A. C.; ROCHA, H. G.; ROCHA, C. F. D. Invasion by Artocarpus heterophyllus (Moraceae) in an island in the Atlantic Forest Biome, Brazil: distribution at the landscape level, density and need for control. Journal of Coastal Conservation, New York, v. 20, n. 3, p. 191-198, 2016. https://doi.org/10.1007/s11852-016-0429-9

DIAS, N. S.; BLANCO, F. F.; SOUZA, E. R.; FERREIRA, J. F. S.; SOUSA NETO, O. N.; QUEIROZ, I. S. R. Efeitos dos sais na planta e tolerância das culturas à salinidade. In: GHEYI, H. R; DIAS, N. S.; LACERDA, C. F. (Ed.) Manejo da salinidade na agricultura: estudos básicos e aplicados. Fortaleza: INCTSal, 2016. p. 151-162.

DICKSON, A.; LEAF, A. L.; HOSNER, J. F. Quality appraisal of white spruce and white pine seedling stock in nurseries. The Forest Chronicle, Mattawa, v. 36, n. 1, p. 10-13, 1960. https://doi.org/10.5558/tfc36010-1

DINIZ NETO, M. A.; SILVA, I. D. F.; CAVALCANTE, L. F.; DINIZ, B. L.; SILVA, J. C.; SILVA, E. C. Mudas de oiticica irrigadas com águas salinas no solo com biofertilizante bovino e potássio. Revista Brasileira de Engenharia Agrícola e Ambiental, Campina Grande, v.18, n.1, p. 10-18, 2014. https://doi.org/10.1590/S1415-43662014000100002

DUNEA, D.; NEAGU FRĂSIN, L. B.; DINCĂ, N. Ecophysiological responses of white clover - hybrid ryegrass mixture to foliar fertilization. Notulae Botanicae Horti Agrobotanici Cluj-Napoca,Cluj-Napoca, v. 43, n. 1, p. 173-178. 2015. https://doi.org/10.15835/nbha4319918

EMBRAPA. Manual de métodos de análise de solo. Manual de análises químicas de solos, plantas e fertilizantes. 3. ed. Brasília: Embrapa, 2017. 627p.

EMBRAPA. Sistema brasileiro de classificação de solos. 5. ed. Brasília: Embrapa, 2018. 353p.

FERREIRA, D. F. Sisvar: a Guide for its Bootstrap procedures in multiple comparisons. Ciência e Agrotecnologia, Lavras, v. 38, n. 2, p. 10-17, 2014. https://doi.org/10.1590/S1413-70542014000200001 
HOLANDA, J. S.; AMORIM, J. R. A.; FERREIRA NETO, M.; HOLANDA, A. C.; SÁ, F. V. S. Qualidade da água para irrigação. Em: GHEYI, H. R; DIAS, N. S.; LACERDA, C. F. (Ed.) Manejo da salinidade na agricultura: estudos básicos e aplicados. Fortaleza: INCTSal, 2016. p. 35-82.

HUSSAIN, M., AHMAD, S.; HUSSAIN, S.; LAL, R.; UL-ALLAH; NAWAZ, A. Rice in saline soils: Physiology, biochemistry, genetics, and management. Advances in Agronomy, San Diego, v. 148, n. 1, p. 233287, 2018. https://doi.org/10.1016/bs.agron.2017.11.002

LIMA NETO, A. J.; CAVALCANTE, L. F.; MESQUITA, F. O.; SOUTO, A. G. L.; SANTOS, G. P.; SANTOS, J. Z.; MESQUITA, E. F. Papaya seedlings irrigation with saline water in soil with bovine biofertilizer. Chilean Journal of Agricultural Research, Chillán, v. 76, n. 2, p. 235-241, 2016. https://doi.org/10.4067/S0718-58392016000200014

LIMA NETO, A. J. L.; CAVALCANTE, L. F.; NUNES, J. C.; BEZERRA, F. T. C.; CAVALCANTE, A. G. Biometric variables and photosynthetic pigments in tamarind seedlings irrigated with saline water and biofertilizers. Semina: Ciências Agrárias, Londrina, v. 39, n. 5, p. 1909-1920, 2018. https://doi.org/10.5433/1679-0359.2018v39n5p1909

MADRUGA, M. S.; ALBUQUERQUE, F. S. M.; SILVA, I. R. A.; AMARAL, D. S.; MAGNANI, M.; QUEIROGA NETO, V. Chemical, morphological and functional properties of Brazilian jackfruit (Artocarpus heterophyllus L.) seeds starch. Food Chemistry, London, v. 15, n. 143, p. 440-445, 2014. https://doi.org/10.1016/j.foodchem.2013.08.003

MEDEIROS, R. F.; CAVALCANTE, L. F.; RODRIGUES, R. M.; MESQUITA, F. O.; BRUNO, R. L. A.; FERREIRA NETO, M. Uso de biofertilizantes e águas salinas em plantas de Licopersicon pimpinellifolium $\mathrm{L}$. Revista Brasileira de Ciências Agrárias, Recife, v. 8, n. 1, p. 156-162, 2013. https://doi.org/10.5039/agraria.v8i1a1679

MELLEK, J. E.; DIECKOW, J.; SILVA, V. L.; FAVARETTO, N.; PAULETTI, V.; VEZZANI, F. M.; SOUZA, J. L. M. Dairy liquid manure and no-tillage: Physical and hydraulic properties and carbon stocks in a Cambisol of Southern Brazil. Soil \& Tillage Research. Amsterdam, v. 110, n. 1, p. 69-76, 2010. https://doi.org/10.1016/j.still.2010.06.005

NEGRÃO, S.; SCHMÖCKEL, S. M.; TESTER, M. Evaluating physiological responses of plants to salinity stress. Annals of Botany, London, v. 119, n. 1, p. 1-11, 2017. https://doi.org/10.1093/aob/mcw191

OLIVEIRA, F. Í. F.; DE SOUTO, A. G. L.; CAVALCANTE, L. F.; MEDEIROS, W. J. F.; BEZERRA, F. T. C.; BEZERRA, M. A. F. Quality of jackfruit seedlings under saline water stress and nitrogen fertilization. Semina: Ciências Agrárias, Londrina, v. 38, n. 4, p. 2337-2350, 2017. https://doi.org/10.5433/16790359.2017v38n4SUPLp2337

OLIVEIRA, F. Í. F.; SOUTO, A. G. L.; CAVALCANTE, L. F.; MEDEIROS, W. J. F.; MEDEIROS, S. A.S.; OLIVEIRA, F. F. Biomass and chloroplast pigments in jackfruit seedlings under saline stress and nitrogen fertilization. Revista Caatinga, Mossoró, v. 31, n. 3, p. 622-631, 2018. https://doi.org/10.1590/1983$21252018 \mathrm{v} 31 \mathrm{n} 310 \mathrm{rc}$

PARIHAR, P.; SINGH, S.; SINGH, R.; SINGH, V. P.; PRASAD, S. M. Effect of salinity stress on plants and its tolerance strategies: a review. Environmental Science and Pollution Research, Berlin, v. 22, n.6, p. 4056-4075, 2015. https://doi.org/10.1007/s11356-014-3739-1

RICHARDS, L. A. Diagnosis and improvement of saline and alkaline soils. 1. ed. Washington: United States Salinity Laboratory Staff, 1954. 160p. 
SÁ, F. V. D. S.; BRITO, M. E. B; MELO, A. D.; ANTÔNIO NETO, P.; FERNANDES, P. D.; FERREIRA, I. B. Produção de mudas de mamoeiro irrigadas com água salina. Revista Brasileira de Engenharia Agrícola e Ambiental, Campina Grande, v.17, n.10, p.1047-1054, 2013. https://doi.org/10.1590/S141543662013001000004

SÁ, F. D. S.; BRITO, M. E. B.; FERREIRA, I. B.; ANTÔNIO NETO, P.; SILVA, L. A.; COSTA, F. B. Balanço de sais e crescimento inicial de mudas de pinheira (Annona squamosa L.) sob substratos irrigados com água salina. Irriga, Botucatu, v.20, n.3, p.544-556, 2015. https://doi.org/10.15809/irriga.2015v20n3p544

SHELDON, A. R.; DALAL, R. C.; KIRCHHOF, G.; KOPITTKE, P. M.; MENZIES, N. W. The effect of salinity on plant-available water. Plant and Soil, Hague, v. 418, n. 1-2, p. 477-491, 2017.

https://doi.org/10.1007/s11104-017-3309-7

SOUSA, G. G., VIANA, T. V. A., LACERDA, C. F.; AZEVEDO, B. M.; SILVA, G. L.; COSTA, F. R. B. Estresse salino em plantas de feijão-caupi em solo com fertilizantes orgânicos. Revista Agro@mbiente, Boa Vista, v. 8, n. 3, p. 359-367, 2014. https://doi.org/10.5327/Z1982-8470201400031824

SOUTO, A. G. L.; CAVALCANTE, L. F.; NASCIMENTO, J. A. M.; MESQUITA, F. O.; LIMA NETO, A. J. Comportamento do noni à salinidade da água de irrigação em solo com biofertilizante bovino. Irriga, Botucatu, v. 18, n. 3, p.442-453, 2013. https://doi.org/10.15809/irriga.2013v18n3p442 